\title{
Admiration in Place of Imitation: Four Medallions by Gustaw Herling-Grudziński ${ }^{1}$
}

\section{Towards genology, i.e. escaping it}

In Gustaw Herling-Grudziński's output one might identify a small set of texts devoted to painters. Their genological status is uncertain. It is significant (and it hampers any classification at the same time) that the writer included these works in his journal ${ }^{2}$. Similarly to his short stories, they too are part of a greater whole, namely Dziennik pisany noca [The Noonday Cemetery and Other Stories], a kind of Herling-Grudzinski's opus magnum. The author's decision stemmed from, as I see it, the need to utilise the autobiographical interpretative key in their analysis, which can be even more surprising as the texts are not devoted to current affairs, but to past painters, their biographies and works. Those works were created in 19901992 and all were included in Dziennik pisany noca 1989-1992. They exist in it alongside texts such as Kiet Barabasza [The Eyetooth of Barabbas] and Cmentarz potudnia. Opowiadanie otwarte [The Noonday Cemetery: An Open Story], which can undoubtedly be considered as short stories. In the case of the latter one, the author himself indicated the genre ('opowiadanie otwarte' [an open short story]) in the subtitle. However, it would be difficult to regard

1 This article is a part of research project funded by the National Science Centre. The post-doc grant was awarded pursuant to the decision DEC-2015/16/HS2/00133.

2 Regarding the hybrid nature of the genre of The Noonday Cemetery and Other Stories, vide B. Witosz, 'Dziennik pisany noca': Między gatunkowym a indywidualnym stylem wypowiedzi, "Język Artystyczny" 2001, vol. 11, pp. 29-46. 
the texts on Caravaggio, Rembrandt, Vermeer or Ribera as short stories. So what are they?

A small genological hint was included in the title of the text on Rembrandt: Rembrandt $w$ miniaturze [Rembrandt in Miniature]. In this case, a question immediately arises about what a miniature is or what kind of a miniature Herling-Grudziński was referring to. In Słownik terminów literackich [A Dictionary of Literary Terms], two separate entries exist: a miniature understood as a small illustration and illumination, and a poetic miniature, i.e. a small poetic work ${ }^{3}$. So what is one supposed to do with non-rhymed literary miniatures?

Herling-Grudziński began his text about Rembrandt with a discussion of the status of a text while indicating that he was not concerned with debates on a genre affiliation but, rather, with authors' intentions:

In a miniature or in nuce? It doesn't matter, what matters is the intention (and the desire) of the writer. I intend to miniaturise a giant, I wish to extract the core of his genius, similar to a gem with many facets, to a pearl with many shades, describe with utmost conciseness several of those as I believe that love for grand artists, just like falling in love with one person, is a feeling which demands an embarrassing economy with words. The greater the love, the fewer the words. Savour the art of your beloved, speak up when you truly have to, admire his masterpiece while in a rarely disturbed silence. $(\mathrm{RwM}, 171)^{4}$

Herling-Grudziński did not engage in a genological debate. He somewhat dismissed any attempts at this made by readers by posing a question and answering with a telling "Wszystko jedno" ["Whatever"]. What was more important to him was to convey silence (understood as admiration and meditation), hence the frugality with words. Therefore, the titular miniaturisation should be read as lapidariness, a kind of discreteness, but also the creation of a literary illustration, a mini-portrait of a painter, i.e. a medallion. It is no accident that all four texts that I shall focus on were included in the 1994 collection titled Sześć medalionów i Srebrna Szkatutka [Six Medallions and a Silver Casket]. The fourth cover page of the book reads:

In the ovals of the six title medallions, there appear the portraits of Parma and Siena - two of the numerous Italian treasure troves of wonderful works of architecture and art - and then the images of four painters: Caravaggio, the revolutionist, Rembrandt, the genius, Vermeer van Delft, the mystery

\footnotetext{
${ }^{3}$ Vide M. Głowiński, Miniatura, and T. Kostkiewiczowa, Miniatura poetycka, [in:] Słownik terminów literackich, ed. J. Sławiński, Wrocław-Warsaw-Kraków 1998, p. 311.

${ }^{4}$ G. Herling-Grudziński, Dziennik pisany noca 1989-1992, Warsaw 1997, p. 104. I quote all the texts about painters from this edition referencing the quotations directly in the text and indicating an abbreviation and a page number. C - Caravaggio: światło i cień [Caravaggio: Light and Shadow], RwM - Rembrandt w miniaturze [Rembrandt in Miniature], PV - Perty Vermeera [Vermeer's Pearls], R - Ribera - Hiszpańczyk Partenopejski [Ribera: A Parthenopean Spaniard]. [Unless indicated otherwise, quotations in English were translated from Polish]
} 
man, and Jusepe Ribera, the "master of Spanish rural realism". The true gem of the collection is the story about a Silver Casket - an object which is beautiful and just as fascinating due to the mystery it holds. ${ }^{5}$

The next genological hint left by Herling-Grudziński, according to which texts devoted to the painters ought to be treated as medallions, proves extremely broad: it includes both a piece of information about the miniature dimensions of a work of literature and a suggestion that it offers an image, a representation of the face, a special form of portrait, valued highly by Herling-Grudziński; moreover, a medallion is also a form of commemorating people, which is why it can be treated as a kind of a diary. Finally, by defining his works as "medallions", the writer placed clear emphasis on the significance of the biographical context.

For the sake of clarity, one should note that in the Dzieta zebrane [Collected Works] series edited by Włodzimierz Bolecki, the works appeared in 2017 in the Eseje [Essays] volume ${ }^{6}$. However, I would like to stress that even if those texts could theoretically be attributed with many 'names ${ }^{7}$, I believe that Herling-Grudziński's "medallion" most comprehensively indicates their specificity and humble - very miniature-like - richness.

What seems absolutely crucial is the fact that in the titles of Herling-Grudziński's medallions, there appear the names of painters in whom the writer was interested. I shall list these works in chronological order - Caravaggio: światło i cień (March 1990), Rembrandt w miniaturze (November 1990), Perty Vermeera (July 1991), Ribera - Hiszpańczyk Partenopejski (March 1992). What is worth emphasising is that Herling-Grudzinski did not select contemporary artists; he mainly focused on the 17th-century art (though the biographies of Caravaggio and Ribera, and in the case of the former one also his artistic career, began in the second half of the 16th century). The writer often stressed that he did not find painting experiments by many modern artists appealing even though these included Cézanne, Turner, van Gogh, Modigliani or Morandi, whose works were particularly close to him. If one finds a discussion of painting in his texts, it is usually an interpretation of the art of the past centuries ${ }^{8}$.

All four medallions have similar structures. Herling-Grudziński focused in them on biographies and selected paintings (calling them "pearls" and, interestingly enough, he did not do so exclusively in Perty Vermeera), though he did not avoid remarks in which the author's ' $\mathrm{I}$ ' came to the

${ }^{5}$ G. Herling-Grudziński, Sześć medalionów i Srebrna Szkatułka, Warsaw 1994, 4th cover page.

${ }^{6}$ Vide G. Herling-Grudziński, Dzieła zebrane, [in:] ed. W. Bolecki, Eseje, vol. 10, Kraków 2017.

${ }^{7}$ I am referring to a concept by Roma Sendyka, who called various traditionally established definitions of the essay with his original names. Vide R. Sendyka, Nowoczesny esej. Studium historycznej świadomości gatunku, Kraków 2006, pp. 15-16.

${ }^{8}$ Vide 'Cienie wielkich artystów'. Gustaw Herling-Grudziński i dawne malarstwo europejskie, eds. A. Stankowska, M. Śniedziewska, M. Telicki, Poznań 2013; M. Śniedziewska, Siedemnastowieczne malarstwo holenderskie w literaturze polskiej po 1918 roku, Torun 2014; M. Śniedziewska, Niekonwencjonalne portrety. 'Madonna del Parto' Piera della Francesca i 'Betsabee' Rembrandta w oczach Herlinga, [in:] Świadectwo - mit - tajemnica. O Gustawie Herlingu-Grudzińskim, ed. Z. Kudelski, Warsaw 2019, pp. 275-296. 
foreground. Each time he strived to find and propose an original interpretative key present in the works, as if placed in it immanently. He also utilised quotations (usually from the works of art historians or writers who discussed the painters he was interested in), which became the starting point of a small yet significant polemics; to a lesser extent, he used them to prove his theses. However, one might get the impression that Herling-Grudziński spoke not because he wished to place himself in opposition to the findings of art historians; he neither wished to dispute nor supplement their studies, but he decided to voice his opinions as he had things to say which, from his perspective, were important. He did not conceal the fact that he assumed the point of view of an amateur specialist - he formulated judgements as a creator of literature, for whom his fascination with painting was a course of endless inspiration. When interviewed by Bolecki, the writer stressed: "I do not, of course, intend to compete with people who devoted their whole lives to studying art and who know their craft well, even though their opinions are not always convincing for me," and he added: "I am not entering, as Shakespeare said in Hamlet, between the blades of grand fencers, I observe art "from aside»" . It seems that this viewing "from aside" was the core of Herling-Grudziński's writing strategy. The author of Sześć medalionów i Srebrna Szkatutka did not consider himself a specialist in art, yet he suggested that the fact of being 'beside' did not necessarily mean ignorance; it was merely a different mode of contemplating painting.

In his medallions, Herling-Grudziński examined various labels which have been used to classify his favourite painters. He argued that any attempt at classifying them was reductionist and unfair. The text titled Caravaggio: światto $i$ cien opens with a discussion on naturalism and realism as notions which are supposed to define the poetics of Caravaggio's output. Herling-Grudziński approached such generalisations with exceptional care, if not distance:

If Caravaggio is supposed to appear as the originator of the house of "naturalists" and "realists", one can with clear conscience disregard all the inclinations towards classification-based naming. He opened in the history of painting a chapter which was the opposite of all types of pigeonholing; one which is mysterious, ambiguous and offers various registers, and which transcends the canons of vision and craft available for the eye. So what if we attach to him the label of a "realist"? Is it even possible to frame the "reality" painted by Caravaggio within any pattern? (C, 104)

The writer asked about the cognitive benefit of calling Caravaggio a realist. He questioned the utility of a classification particularly when discussing an outstanding artist whose genius manifested itself in ambiguity, in transcending conventions and breaking patterns, in a fluent transition between various languages of painting. Herling-Grudziński did not, however, dispute people's intention to classify altogether (though he discussed them with a pinch of salt):

${ }_{9}^{9}$ G. Herling-Grudziński, W. Bolecki, Rozmowy w Dragonei, Warsaw 1997, p. 364. 
The classification mania is acceptable, if absolutely necessary, when discussing an artist with a specific and distinct philosophical profile. It is too tight and even ridiculous regarding the tumultuous revolutionary changes in arts. Caravaggio was a revolutionary. Like a river in spate, he flooded the surrounding area. He broke through dividers and dams. In a sense, he himself was not in control, including as a painter, of the power and violence hidden inside him. (C, 104-105)

In the context of this discussion, I would like to examine my own inclination to classify: the attempt to specify the genological status of the four texts on Caravaggio, Rembrandt, Vermeer, and Ribera. In drawing conclusions from thus formulated judgement, one could ask: what difference does it make if I assign these texts the labels of 'medallions', 'studies', 'miniatures' or 'essays' when what is more important is their literary power, the potential of Herling-Grudziński's imagination, and the writer's lesson in admiring painting? In fact, Dziennik pisany noca itself, which includes these texts, is - to use Herling-Grudziński's words about Caravaggio - "mysterious, ambiguous, and it offers various registers, and it transcends the canons of vision and craft available for the eye". Herling-Grudziński moulded it out of texts of various genological statuses, intentionally not striving for its coherence either in terms of the topic or form. Additionally, he plays with the etymology of the word 'dziennik' [journal], pointing out that the time of creating is other than daytime ["pisany noca" means "written at night"]; thus, the titular expression includes a paradox, the significance of which can be utilised in different ways.

However, there were situations (not so rare, in fact) when Herling-Grudziński seemed to yield to organising inclinations, intentionally stressing genre affiliations in the titles of his works. I am referring to texts such as: Inny Świat. Zapiski sowieckie [A World Apart: The Journal of a Gulag Survivor]; Drugie Przyjście. Opowieść średniowieczna [The Second Coming: A Mediaeval Story]; Z biografii Diego Baldassara [From the Biography of Diego Baldassar]; Piętno. Ostatnie opowiadanie kotymskie [Stigma: The Final Kolyma Story]; Ugolone $z$ Todi. Nekrolog filozofa [Ugolone Da Todi: An Obituary of a Philosopher]; Krótka spowiedź egzorcysty [The Exorcist's Brief Confession]; Dżuma w Neapolu. Relacja o stanie wyjatkowym [The Plague in Naples: An Account of a State of Emergency]; Monolog o martwej mniszce [A Monologue About a Dead Nun]; Cmentarz Potudnia. Opowiadanie otwarte [The Noonday Cemetery and Other Stories]; Zeszyt Williama Mouldinga, emeryta [The Notebook of William Moulding, Pensioner]; Portret wenecki [A Venetian Portrait]; Rosyjski niedźwiedź. Divertimento narracyjne [A Russian Bear: A Narrative Divertimento]; Szczyt lata. Opowieść rzymska [A Peak of Summer: A Roman Story]; Madrygat żałobny [A Madrigal of Mourning]; Legenda o nawróconym pustelniku [A Legend of a Converted Hermit]; Ofiarowanie. Opowieść biblijna [The Offering: A Biblical Story]; Zima w zaświatach. Opowieść londyńska [Winter in the Beyond: A London Story]; Zielona Kopuła. Sycylijska opowieść epistolarna [The Green Copula: A Sicilian Epistolary Story]; Biała noc miłości. Opowieść teatralna [A White Night of Love: A Theatre Story]; Odlot i powrót Gotubowa. Opowieść imperialna [Golubov's Departure and Return: An Imperial Story]. 
The most common subtitle further specifying the kind of text that readers are about to read is "opowieść" [a story] (with the accompanying epithets). A special case is Zielona Kopuła. Sycylijska opowieść epistolarna, which features the additional genologically loaded adjective "epistolarna" [epistolary], through which Herling-Grudziński stressed that this story would manifest in the form of letters. Considering the definition in Stownik terminów literackich, only Biała noc mitości could actually be referred to as a story, since Janusz Sławiński defined a story as a "narrative prose text the length of which exceeds that of a novella or a short story but is shorter than that of a novel. The story is a genre having not clearly defined morphological assumptions; in today's literary perception, it possesses a strictly relational nature: it is classified exclusively as an intermediate type between long and short epic forms which covers works close to either «short novels» or «long short stories»"10.

However, I believe that Herling-Grudziński was not focused on the length of a text when he defined his works as "opowieści" [stories], but, rather, he cared to attempt to escape any classification. Paradoxically, the special kind of categorisation was supposed to help these texts avoid a rigid genre framework. This conclusion could be drawn from the fragment of the interview by Bolecki regarding the texts Parma and Siena, which, similarly to the works about the painters, were included in Sześć medalionów i Srebrna Szkatutka. In it, Herling-Grudziński confessed: "I am a huge enthusiast of a book which is extremely beautiful and with which I feel related in its description of cities - that is a book by Paweł Muratow entitled Obrazy Wtoch. He approaches Italian cities similarly to how I do, but, of course, with greater historical knowledge than mine as in his books there are several-dozen-pages-long chapters on the histories of cities. Muratow has considerable knowledge about painting, yet he does not overdo with showing it off. It is a story, not an academic study"11. In that instance, he clearly contrasted a story against an academic discourse. Texts filled with facts, in which what mattered was only the knowledge of the one who writes, did not stimulated Herling-Grudziński's imagination. He was a proponent of writing not for a tight circle of specialists, but for a wide group of recipients. Thus, the inclination of a text towards a "story" became the measure of its accessibility. This is why Herling-Grudziński's output includes so many "stories".

Therefore, it can be surprising that the subtitle of one of his works includes the word "opowiadanie" [short story]. Yet, even this seemingly firm category was intentionally opened by Herling-Grudziński in Cmentarz Potudnia [The Noonday Cemetery]. Therefore, he intentionally engaged in a play with the genological inclinations of literary scholars, and he applied evasions positioning himself rather on the side of ambiguity than of any rigid genre framework. A similar situation applied to other labels, such as "zapiski" [notes], "divertimento narracyjne" [narrative divertimento], "madrygat" [madrigal], "spowiedż" [confession], "legenda" [legend], "nekrolog" [obituary],

${ }^{10}$ J. Sławiński, Opowieść, [in:] Stownik terminów literackich, p. 359.

${ }^{11}$ G. Herling-Grudziński, W. Bolecki, op. cit., p. 377. 
"relacja" [account], "z biografii" [from biography] or "zeszyt" [notebook]. These designations were both specifying and enabling new options for interpretation. Thus, as I decided to choose Herling-Grudziński's formula of "medallions", I am not closing the discussion on the genological status of his works on old painters; on the contrary, I am intentionally leaving it opened as Herling-Grudziński's writing "needs to remain opened. Opened (...) to all sides, depending on the sensitivity and imagination of readers ${ }^{\prime \prime 2}$.

\section{The writer's Self, i.e. on the power of imagination}

When asked by Włodzimierz Bolecki in an interview titled Teksty o malarstwie [Texts on Painting] about the intertwining of biographies and art in his texts devoted to Caravaggio, Rembrandt, Vermeer, and Ribera, and the fact of including the author's Self in the discussion, Herling-Grudziński stressed: "Among my studies, the most exemplary is the one about Ribera - upon viewing his paintings, I look at him as a co-émigré from Naples. I once said that I had come to terms with living in Naples, yet that happened thanks to that what I knew about Ribera's life in Naples. So that is certainly an extremely personal text"13. The Ribera - Hiszpañczyk Partenopejski medallion actually begins with a presentation of Mergellina. It would not have been strange (considering that Ribera was associated with this borough of Naples) if not for the personal confession of the author which precedes the description of the borough: "Usually, for many years, my longer walks led me to the Mergellina fishing port. Since my heart attack, they became obligatory curative walks prescribed by my doctor" $(\mathrm{R}, 348)$. Therefore, the model nature of the text about Ribera hinged on the fact that Herling-Grudziński focused in it not exclusively on the painter's biography and the mark his Naples fortunes had on his works, but he also developed the story along two lines: he intentionally included in the discussion a very distinct autobiographical thread, which enabled him to better understand the Spaniard's life. This complicated relationship was deep and, in a way, bilateral as the fact of knowing about Ribera's life helped Herling-Grudziński - after the many years of his struggles with his new place of residence - to fully accept Naples as his town. When unfolding his reflections on Ribera's life and works, the writer was surprisingly sure of his statements. He wrote of the artist's "zrośnięcie" [growing into] Naples, the inhabitants of which made him their "przybrany syn" [adopted son] (R, 348); he was convinced that in the painting titled Communion of the Apostles "Ribera knew that he was painting his final painting" ( $R, 352)$. He imagined the artist nearing his demise as he timidly ascended the ladder to finish his work, and he stressed that Ribera felt reconciled with Naples, which he chose as the place where he would die. Therefore, on the one hand, Herling-Grudziński created in his imagination consecutive key stations in the painter's life, and, on the other, he wrote as if he knew. There is no contradiction in this as the writer was in fact offering

12 G. Herling-Grudziński, Cmentarz Południa. Opowiadanie otwarte, [in:] idem., Dziennik pisany noca 1989-1992, p. 287.

${ }^{13}$ G. Herling-Grudziński, W. Bolecki, op. cit., p. 367. 
an account of his own experiences. These were autobiographical reflections of polacco napoletano ${ }^{14}$, which Herling-Grudziński assigned to Ribera.

Therefore, one can see that even in the case of a text devoted to another artist, Herling-Grudziński intentionally included his autobiographical Self in it. Yet it was not an expression of self-love but, rather, an attempt to learn something about himself, a kind of a literary self-analysis. In this he resembled Rembrandt, about whom he wrote that:

The sheer number of self-portraits throughout Rembrandt's life, starting with the youth one in the rimmed collar and ending with a series of three in the final five years prior to his death is not a proof of or a subconscious reflex of his egotism. An egotist painter would not have looked at himself with such cruelty as the Rembrandt smiling with a senile toothless grin, maybe not one step away from his grave, but surely having it within an eye's reach. In his self-portraits, Rembrandt intended to systematically and persistently monitor his own face as an expression of his mental changes. (RwM, 173)

In this context, no one should be surprised by the multitude of self-portraits which can be found in Herling-Grudziński's works. As the narrator of short stories, Herling-Grudziński offered readers an examination of himself - his work is filled with so many literary self-portraits that one could consider him the Rembrandt of literature, who intentionally and with exceptional awareness presented his face to the readers. Literary egotism? Certainly not. Herling-Grudziński, similarly to Rembrandt, viewed himself in a 'cruel' way, on the one hand using artistic conventions and, on the other, trying to remain honest when writing about himself. In Dziennik pisany noca, he spoke overtly of leaving an author's trace in his texts. Interestingly enough, he once again used notions of "miniaturowy" [miniature] and "autoportret" [self-portrait] from the area of fine arts, which is significant from the point of view of this discussion.

For me, the perfect journal, a version which I consider unequalled, is the truth - yet there is no reason not to profess it. In it, there shifts, sometimes quicker, sometimes slower, sometimes in the foreground, and sometimes in the back, the "history set loose" as Jerzy Stempowski aptly defined our times. And in the left-hand lower corner, emulating some Renaissance paintings, there is a miniature and roughly sketched self-portrait of the observer and chronicler. ${ }^{15}$

${ }^{14}$ I discussed this in more detail in the chapter titled Conrad, Joyce i Ribera jako 'wspólnicy losu', [in:] M. Śniedziewska, 'Osobiste sprawy i tematy'. Gustaw Herling-Grudziński wobec dwudziestowiecznej literatury włoskiej, Warsaw 2019, pp. 63-71. Regarding the importance of the 'Italian autobiography' in Herling-Grudziński's short stories, vide A. Ajres, L'autobiografia italiana nei racconti di Gustaw Herling-Grudziński, Rome 2018. In this book, Alessandro Ajres discussed how the fact of using his own biography in his works of literature enabled Herling-Grudziński to extract a kernel of the great mystery of existence. Ibid., p. 15. phasis - M.Ś.)

15 G. Herling-Grudziński, Dziennik pisany noca 1973-1979, Warsaw 1995, pp. 388-389 (em- 
The self-portrait (similarly to medallions, miniatures, and portraits) in Herling-Grudziński's works acquired the status of a notion which referred to both painting and literature. He intentionally blurred the line between these two different art forms. He did, however, stress that a self-portrait was not the central element of his work. Quite the opposite: it was a humble miniature signature and yet an exceptionally significant gesture confirming his presence. This is not surprising when the medium is a journal.

It was by no accident that Herling-Grudziński included autobiographical threads also in his discussions of painters and their works. The author's Self is most visible in the fragments in which he allowed himself to be carried away by his imagination. Even if realising that he was only guessing or making things up, he shared his observations with the readers. He thus wrote about Rembrandt: "I see him (though that is probably my purely personal view) as a painter who new sought out anything in others, who only drew from himself, who reproduced, expanded and imitated only his own visions" (RwM, 172), even if such claims were disputed in works by art historians (e.g. Rembrandt and the Italian Renaissance by Kenneth Clark ${ }^{16}$, a researcher of old-time painting, whom Herling-Grudziński appreciated and quoted). In another location, in interpreting one of Rembrandt's masterpieces (and entering into a polemic with Svetlana Alpers ${ }^{17}$, who wrote about the Dutch master's theatre model), he concluded:

\begin{abstract}
The magnificent The Night Watch is a separate chapter. The proponents of Rembrandt's "theatricality" have found various arguments in it for supporting their thesis: the armed men seem to enter the stage as if in Shakespeare's drama, the fragment of the gate visible in the background could be the scenery. Yet I think that Rembrandt painted much more than the turmoil of war, an army patrol surrounded by a crowd in a besieged town. The scene is too lively, too authentic for the pacing figures to sound the squeaking boards of a stage. (RwM, 175)
\end{abstract}

The polemic interpretation is introduced with the words: "Yet I think that Rembrandt painted much more". Once again, the readers saw Herling-Grudziński appearing only when he had something new and important to say. Then, he concluded a fragment describing a made-up scene of Rembrandt's death with the words: "It doesn't matter, it completely does not matter whether this was how Rembrandt died. This is how I imagined his death" (RwM, 180). His fascination with Rembrandt's self-portraits brought Herling-Grudziński to formulating unverifiable assumptions about the moment of the Dutch master's demise. What was important to the writer was not the historical truth but, rather, literary vision which enabled him to come closer to Rembrandt as a human who struggled with the mystery of his own face. Herling-Grudziński applied a similar rhetorical figure in the text about Caravaggio:

\footnotetext{
${ }^{16}$ K. Clark, Rembrandt and the Italian Renaissance, London 1966.

17 S. Alpers, Rembrandt's Enterprise: The Studio and the Market, Chicago 1990.
} 
On 17 February 1600 Caravaggio was most certainly in Rome. Yet only one of his biographers mentioned that he was seen quickly crossing Campo dei Fiori and "do the sign of the cross" while turning away from the stake. He did not take a knee; he only did the sign of the Cross to fend off the Evil Power.

I do not believe in that version. In my imagination I see Caravaggio sitting until the evening in a corner tavern, at the corner of the street that leads to Palazzo Farnese, his face more than angry - furious rather, motionless, turned towards the burning stake. In the evening, when Campo dei Fiori became less crowded, he rose, drank the last glass of wine in one gulp, and slightly tottering crossed the entire square to stop at the pile of smoking ash. Suddenly, a bright flame burst as if only at that moment Bruno's soul escaped for the Heaven. Caravaggio stepped back blinded by the Light of the dying stake. He stood in the Shadow and used his clenched fists to hide his face which we know from his self-portrait in Goliath's severed head. (C, 112-113)

There, too, his inclination for polemics on the one hand and the power of his imagination on the other became visible. The phrase "in my imagination" could be considered as the definition of Herling-Grudziński's literary devices as he strived to miniaturise master painters.

All four medallions include important fragments in which he recalled biographical details important from his point of view. In the text about Rembrandt, he stressed that the context of the artist's life was one of major interpretative keys enabling one to understand the series of paintings in which the Dutch master portrayed himself: "One needs to know that life not to satisfy own biographical curiosity, but to better understand Rembrandt's self-portraits" (RwM, 173). These words could be paraphrased and referred to their author: "To understand (having traced) the self-portraits scattered around Herling-Grudziński's work, one first needs to learn about his life".

In this context, one should not be surprised by the discussion regarding Vermeer, whose art - veiled in mystery - the writer wished to read by analysing the exceptionally strong bonds which connected the painter and his family town:

Among all the questions, hesitations, and doubts which I have indicated above, the most significant is, in my opinion, Vermeer's chaining to Delft; no, no, chaining suggests pressure while in this case it was more of a devotion, love for one place. I understand the temptation of sending Vermeer to Amsterdam, to visit Rembrandt; I share the desire of the imagination to see them together, next to each other, Rembrandt showing his guest Susanna and the Elders and Vermeer unwrapping Girl in a Turban, a gift for the host. The imagination's drive emboldens one even to listen on to what they are saying. Yet for the attempts to penetrate Vermeer's secret what is worth much more are his forty-three years of motionless embedding in Delft than yielding to the rushing meanders of imagination. In order to come closer to him, it is best to state at the start: he never crossed the limits of his family town. (PV, 255-256) 
Yet Herling-Grudziński sought not only an answer to the question about the artist's tangled fortunes. He also tried to find a unique interpretative key which would enable him to come closer to the mystery of his art. In discussing the topic of the special use of light in Rembrandt's paintings, the writer formulated the following hypothesis: "About most of Rembrandt's paintings one could say that he painted them intentionally before dusk, when the sun was setting" (RwM, 178), yet a moment later he corrected it by stating that:

The more I think about it, closely examining Rembrandt's paintings, the more I am tempted to replace the sun's reflection with a reflection of a distant fire glow. Not, of course, to say that Rembrandt literally wrapped the visible world and its biblical or contemporary inhabitants in the glow of fires. I want to believe that like any truly grand artist he utilised his hidden very personal metaphor, in this case a metaphor surrounding us forever at the horizon of flames. (RwM, 179)

The discovery of that "hidden very personal metaphor" proved a challenge for the writer, but it was also the reason for him deciding to start writing in the first place. This creative strategy could be reproduced in its fullest with the use of the example of Perty Vermeera. The titular pearl - growing slowly, almost imperceptibly - became the key for uncovering the secret of both the biography (a kind of amalgamation with Delft) and Vermeer's output; in the painting discourse he reflected the notion of "frozen time". In this medallion, Herling-Grudziński overtly characterised his texts about Caravaggio, Rembrandt, Vermeer, and Ribera: "I, not being an art historian, disregard judgements and explanations which are balanced, based on the so-called concrete premises, and in my images of selected painters I seek something completely different. What? The same thing which constitutes the basis for a short novella: a poetic core; in the case of the images of painters - the poetic cores of their art" (PV, 262).

\section{Admiration in place of imitation. On ekphrasis}

Being a painting enthusiast, Herling-Grudziński identified two notions by means of which one can describe a human being's (usually an artist's, though not always) attitude towards art. These notions are "imitation" and "admiration". He evaluated imitation (which he did not view within the categories of creative emulation) negatively, and juxtaposed it with admiration as the most desirable attitude:

I have already discussed Maria Węgierska's tomb, the figure of a woman lying on the catafalque, who has an oblong face. When I stood in front of the sculpture I cried to my wife who was at that time with me: "But this is Modigliani's face!" And I am very proud that now in relation to the one hundredth anniversary of Modigliani's birthday someone found letters by the teen-aged Modigliani who spent a few months at his relatives' in 
Naples and all the time go and view the tomb of Maria Weggierska by the grand master Tino di Camaiano. So he became charmed by it.

I believe that there are two aesthetic-emotional categories in art. One is imitation, the other is admiration. There are many imitators, all they can do is copy paintings, and usually their works are of poor quality and produce little admiration. Whenever I visited Maisons-Laffitte I visited Józio Czapski and I could see his admiration, at least while he was still visiting exhibitions, because later he almost completely stopped leaving his place. His admiration was not based on the fact that he noticed in someone else's works things which he could introduce in his. He admired fragments of art which he had not previously noticed, or admired the fact that something could be painted differently. In fact, Czapski was like that, he would return home filled with admiration and it was a joy to watch a man happy in seeing beautiful paintings. ${ }^{18}$

How, then, should one understand admiration for art as defined by Herling-Grudziński? First of all, he mentioned painters who admired the works of other painters - who treated them as inspiration, a starting point for painting transformation, and a revision of own skills. Therefore, their goal was not to copy other artists' solutions, but to achieve a creative (r)evolution. Secondly, he also mentioned the admiration of a human being (not necessarily a painter, though his example was Józef Czapski) viewing a painting; a person who feels a kind of happiness when seeing beauty.

What, then, would the admiration by a writer discussing paintings in his texts be? Surely an escape from imitating them: a verbal inventory of colours or the items, figures and scenes collected in a painting. In other words, such writing which would oppose the classically considered ekphrasis, i.e. a precise literary description of a work of art, an act of creating its literary copy. Thus, it should not come as a surprise that classical ekphrasis is hard to find in Herling-Grudziński's texts. Very rarely do his texts include descriptions of works of art, and if some notes on what was painted do appear in them, they are neither detailed nor exhaustive. This is because Herling-Grudziński did not intend to provide a complete description of a painting but, rather, to show how captivated by it he was. Suffice to consider two pearls in Caravaggio's output through Herling-Grudziński's eyes:

Caravaggio followed a certain principle which we shall try to uncover later on. For now, allow pure admiration to do its work, not obscured by any other considerations, admiration when viewing two paintings: The Rising of Lazarus in Messina and The Calling of St. Matthew in the French church in Rome.

A stream of light surrounds the outstretched and still stiff body of Lazarus and the figures holding it; the relatives of the one returned to life, torn away

${ }^{18}$ G. Herling-Grudziński, W. Bolecki, op. cit., pp. 375-376. 
from the clutches of death. The rest of those present move in the shadows. The contrast extracted by Caravaggio becomes a paradox: it is them, that rest, who seem to be immersed in death's darkness while Lazarus, though still dead, has never really departed from life. Caravaggio reversed the conventionality of meanings trying to say (and he did manage that in my opinion) that our divisions and differentiations are frail: Lazarus was alive and only dormant when the dead dug him up. At first, that sounds ridiculously, but one must remember to what a great extent Caravaggio's works were art which blurred excessively clear limits. In the centre of the painting, one of Lazarus' hands rises. It is a combination of light and shadow, a surprising sign from the borderline.

In The Calling of St. Matthew, in the shadows there is Christ pointing to (calling) an illuminated Matthew. In this painting, the role of the hand from The Rising of Lazarus is played by, once again in the centre, a window; matt, neither light nor dark. It is also a mysterious sign of the borderline.

I maintain my position. Caravaggio was a painter of an incessant fight between light and shadow. For him it had the same aftertaste of mystery as the elusive struggle and the mutual permeation of life and death. (C, 107-108)

This clearly indicates how important the notion of "admiration" was to the writer; he further specified it with the epithet "pure", suggesting that that which counts the most is unbiased contemplation which leaves its trace in the memory of the viewer for ever. Herling-Grudziński strived to discover the "poetic core" in Caravaggio's works, making it the guiding principle of his descriptions of the painter's works. Most of all, he wanted to indicate that Caravaggio's paintings featured a Manichean struggle, which was expressed in them through a struggle, perceived metaphorically, of two opposites: light and shadow. Was it not this struggle that Herling-Grudziński always depicted in his texts?

He stressed that in the case of admiration, it is all about the special kind of picking something which one could use in their own works. Yet is it possible to talk about such devices at the division line between two arts: literature and painting? I believe it is. In his works, Herling-Grudziński tried to transfer painting genres (such as miniature, medallion or portrait) onto the field of literature. Additionally, some characters of his short stories - e.g. the protagonist of Błogosławiona, święta or Sebastiano from Pietà dell'Isola - were presented in such a way as if they were elements of a painting representation. And, finally, the literary model of describing landscapes, which occupy a special place in Herling-Grudziński's oeuvre, is extremely vivid. He discussed this overtly in Rozmowy w Dragonei:

I simply love my landscapes. And I could say that what Albert Camus said about them when he came to Italy as a twenty-year-old boy, that landscapes have the power to heal. I completely agree with him. When I spend my time in a landscape, such like, for example now in Dragonea, 
even though I have been coming here for so many years, this landscape still has an extremely soothing effect on me. I am simply attached to this landscape. Landscapes are very important to me, they are something like my private art of painting done with words. I even feel grateful to landscapes for having such a soothing and calming effect on me. I was surprised when I found that note by Camus. ${ }^{19}$

Therefore, one could conclude that Herling-Grudziński, inspired by the landscapes presented by grand painters, became a literary landscaper, thus expressing his fascination with nature. In this context, the fact that since 1955 he lived in Italy seems rather significant. His works were a testimony to his admiration for Italian landscapes, paintings, and architecture. In his writing, he clearly avoided imitation, an act for which he reproached his fellow writer Wojciech Karpiński:

The things he writes cannot be compared to what Zbyszek Berbert writes - not to mention specialists. All in all I am a writer and I can absolutely appreciate what Zbyszek can do and what he has learnt. He has a unique talent of tracing the secrets of painting. That is surprising because he does that with an incredible sense of measure, not losing anything of his poetic potential, which is no easy feat. Allow me to offer an example of a Polish writer and critic in whose case his deep interest in technique changes into boring enumeration. I am referring to Wojciech Karpiński's book about van Gogh, Fajka van Gogha. That is, in my opinion, truly pointless. I am sorry to say this as he is my friend and I appreciate him highly as a writer and a critic, but this is pointless. Such enumerations could be done by Berenson and others, for example enumerating fifteen shades of different colours. That may remain afterwards in the mind of some specialist of painting who knows what all that means, who reads such studies, like a mathematician reading mathematical formulas knowing that one of those shades means something special. But absolutely nothing of that is retained in readers' minds. So I oppose such writings. Zbyszek Herbert never does that. Herbert is very frugal with the use of details and pieces of information. ${ }^{20}$

Herling-Grudziński's point-blank opposition towards enumerations as a creative method could be treated as his rejection of verbal imitation. According to him, focusing on details was destructive, because then one could easily lose the essence of the whole. For similar reasons, Herling-Grudziński criticised Proust, who in his novel made Bergotte - who was viewing Vermeer's masterpiece - focus exclusively on "a little patch of yellow wall":

Let us, then, start with the town, with View of Delft, which Proust called "the most beautiful painting in the world." Proust also considered via Bergotte's eyes the little patch of yellow wall in the right-hand corner of the painting

\footnotetext{
19 Ibid., p. 378 (emphasis - M.Ś.)

20 Ibid., p. 366.
} 
as painted so superbly that if viewed separately it could easily be considered as a creation of "self-contained beauty." In his death-bed delirium, Bergotte kept repeating: "Patch of yellow wall." Such refinements, similar to pointing a finger at "one particular line" in a long poem or "one particular metaphor" in an huge novel, do not naturally lead to anything apart from a flauntable "patent of expertise" so desired by their author. In the case of View of Delft those are even worse because they are irritating. The miracle of the city painted by Vermeer is the miracle of the whole. (PV, 256)

Therefore, one should ask about what Herling-Grudziński proposed in exchange.

View of Delft, i.e. the universe of a home town, reflected at the bottom in the surface of the water, elevated in the broad and tall frame of the sky. The panoramic richness did not prevent the author from perfecting the details, perfecting as if carefully cutting glass, yet free of any excessive pedantic touch of a thin chisel. Also the colour range is richer than usual, while Vermeer's yellow is shifted to the background by the imposing russet shade of the walls and the red of the roofs. The town viewed concurrently in reality and in a dream vision. The figures in the front, on that shore of the sandy shoal, on the other side of the canal, seem cut off from the panorama, excluded from the painting. Seemingly withered Delft yet alive deep inside, precisely as saved from a dream, fortunately not some fleeting, spectre. Underneath in the absolute and secret silence of frozen time something is happening in the dream/real town. Very slowly, in an imperceptible motion, just as a pearl grows and matures in a shell. (PV, 257-258)

Herling-Grudziński used details, yet he managed not to overwhelm readers with excessive detailing. He indicated the colours of the painting, yet his remarks did not lead to a dry enumeration of the pigments used by a given painter. However, what is the most important from his point of view is that he proposed an original literary interpretation of View of Delft, including it in a broader discussion of Vermeer's mythical Delft, the "frozen time", and - the metaphorically perceived - pearl. There may be something too poetic in all this, yet he did express something inexpressible: admiration for a true masterpiece.

The medallions devoted to Caravaggio, Rembrandt, Vermeer, and Ribera are a major collection of texts within Gustaw Herling-Grudziński's entire output. Through them, he proved that he was able to write a moving text about painting while avoiding elements such as the academic tone, flaunting his knowledge, and the dangers of ekphrasis transforming too often into irksome detailed inventories of the elements of a painter's presentation. The decision to refer to these texts as medallions was equally a genological concept and a clever hedge, and a starting point for a discussion of the ambiguity of the very notion of a "medallion". Herling-Grudziński would not 
have been himself if he had abandoned autobiographical reflections. When considering artists and their works "from aside", he multiplied assumptions, proposed apocryphal versions of some biographical threads, and formulated bold unverifiable hypotheses - this was because he sided with a literary story, not an academic discourse. Even if without those texts the grand masters of European art would not have been forgotten, one should appreciate this particular writing effort to protect their biographies and reproduce the original admiration when viewing their painting pearls.

\section{REFERENCES}

Ajres A., L'autobiografia italiana nei racconti di Gustaw Herling-Grudziński, Rome 2018. Alpers S., Rembrandt's Enterprise: The Studio and the Market, Chicago 1990.

'Cienie wielkich artystów'. Gustaw Herling-Grudziński i dawne malarstwo europejskie, eds.

A. Stankowska, M. Śniedziewska, M. Telicki, Poznań 2013.

Clark K., Rembrandt and the Italian Renaissance, London 1966.

Głowiński M., Miniatura, [in:] Słownik terminów literackich, ed. J. Sławiński, WrocławWarsaw-Kraków 1998.

Herling-Grudziński G., Dzieła zebrane, [in:] Eseje, ed. W. Bolecki, vol. 10, Kraków 2017. Herling-Grudziński G., Dziennik pisany noca 1973-1979, Warsaw 1995.

Herling-Grudziński G., Dziennik pisany noca 1989-1992, Warsaw 1997.

Herling-Grudziński G., Sześć medalionów i Srebrna Szkatułka, Warsaw 1994.

Herling-Grudziński G., Bolecki W., Rozmowy w Dragonei, Warsaw 1997.

Kostkiewiczowa T., Miniatura poetycka, [in:] Słownik terminów literackich, ed. J. Sławiński, Wrocław-Warsaw-Kraków 1998.

Sendyka R., Nowoczesny esej. Studium historycznej świadomości gatunku, Kraków 2006.

Sławiński J., Opowieść, [in:] Słownik terminów literackich, ed. J. Sławiński, WrocławWarsaw-Kraków 1998.

Śniedziewska M., Niekonwencjonalne portrety. 'Madonna del Parto' Piera della Francesca i'Betsabee' Rembrandta w oczach Herlinga, [in:] Świadectwo - mit - tajemnica. O Gustawie Herlingu-Grudzińskim, ed. Z. Kudelski, Warsaw 2019.

Śniedziewska M., 'Osobiste sprawy i tematy'. Gustaw Herling-Grudziński wobec dwudziestowiecznej literatury włoskiej, Warsaw 2019, pp. 63-71.

Śniedziewska M., Siedemnastowieczne malarstwo holenderskie w literaturze polskiej po 1918 roku, Toruń 2014.

Witosz B., 'Dziennik pisany noca': Między gatunkowym a indywidualnym stylem wypowiedzi, "Język Artystyczny", 2001, vol. 11.

\section{SUMMARY}

The medallions devoted to Caravaggio, Rembrandt, Vermeer, and Ribera are a major collection of texts within Gustaw Herling-Grudziński's entire output. Through them, he proved that he was able to write a moving text about painting while avoiding 
both the academic tone and flaunting his knowledge, as well as the dangers of ekphrasis transforming too often into irksome detailed inventories of the elements of a painter's presentation. The decision to refer to these texts as medallions was equally a genological concept and a clever hedge, and a starting point for a discussion on the ambiguity of the very notion of a medallion. Herling-Grudziński would not have been himself if he had abandoned autobiographical reflections. When considering artists and their works 'from aside', he multiplied assumptions, proposed apocryphal versions of some biographical threads, and formulated bold unverifiable hypotheses - this was because he sided with a literary story, not an academic discourse.

\section{Keywords}

medallion, ekphrasis, autobiography, Caravaggio, Rembrandt, Vermeer, Ribera

Magdalena Śniedziewska - Ph.D., researcher specialising in Polish and Italian languages, literatures, and cultures; assistant professor at the Department of Theory of Literature, Institute of Polish Philology, University of Wrocław. In 2015-2018, assistant professor at the Department of Historical Poetics, IBL PAN, as part of an NCN post-doc. Author of books: Wierność rzeczywistości. Zbigniew Herbert o postawie wobec świata i problemach jego reprezentacji (Kraków 2013), Siedemnastowieczne malarstwo holenderskie w literaturze polskiej po 1918 roku (Torun 2014), "Osobiste sprawy i tematy". Gustaw Herling-Grudziński wobec dwudziestowiecznej literatury włoskiej (Warsaw 2019), and "Nuta autobiograficzna". O twórczości Gustawa Herlinga-Grudzińskiego (Kraków-Warsaw 2019). She studies the reception of the Italian literature in Poland, the relationships between literature and painting, and bird motifs in the Polish literature.

e-mail: magdalena.sniedziewska@uwr.edu.pl. 